\title{
Contribution of the Locus of Heat Resistance to Growth and Survival of Escherichia coli at Alkaline $\mathrm{pH}$ and at Alkaline $\mathrm{pH}$ in the Presence of Chlorine
}

\author{
Tongbo Zhu ${ }^{1}$, Zhiying Wang ${ }^{1}$, Lynn M. McMullen ${ }^{1}$, Tracy Raivio ${ }^{2}$, David J. Simpson ${ }^{1}(\mathbb{D}$ and \\ Michael G. Gänzle ${ }^{1, *(\mathbb{D})}$
}

check for updates

Citation: Zhu, T.; Wang, Z.; McMullen, L.M.; Raivio, T.; Simpson, D.J.; Gänzle, M.G. Contribution of the Locus of Heat Resistance to Growth and Survival of Escherichia coli at Alkaline $\mathrm{pH}$ and at Alkaline $\mathrm{pH}$ in the Presence of Chlorine.

Microorganisms 2021, 9, 701.

https://doi.org/10.3390/

microorganisms 9040701

Academic Editor: Sylvie Chevalier

Received: 15 February 2021

Accepted: 25 March 2021

Published: 28 March 2021

Publisher's Note: MDPI stays neutral with regard to jurisdictional claims in published maps and institutional affiliations.

Copyright: (c) 2021 by the authors. Licensee MDPI, Basel, Switzerland. This article is an open access article distributed under the terms and conditions of the Creative Commons Attribution (CC BY) license (https:// creativecommons.org/licenses/by/ $4.0 /)$.
1 Department of Agricultural, Food and Nutritional Science, 4-10 Ag/For Centre, University of Alberta, Edmonton, AB T6G 2P5, Canada; tongbo@ualberta.ca (T.Z.); zhiying2@ualberta.ca (Z.W.); lmcmulle@ualberta.ca (L.M.M.); djsimpso@ualberta.ca (D.J.S.)

2 Department of Biological Science, University of Alberta, Edmonton, AB T6G 2E9, Canada; traivio@ualberta.ca

* Correspondence: mgaenzle@ualberta.ca

\begin{abstract}
The locus of heat resistance (LHR) confers resistance to extreme heat, chlorine and oxidative stress in Escherichia coli. This study aimed to determine the function of the LHR in maintaining bacterial cell envelope homeostasis, the regulation of the genes comprising the LHR and the contribution of the LHR to alkaline $\mathrm{pH}$ response. The presence of the LHR did not affect the activity of the Cpx two-component regulatory system in E. coli, which was measured to quantify cell envelope stress. The LHR did not alter E. coli MG1655 growth rate in the range of $\mathrm{pH} 6.9$ to 9.2. However, RT-qPCR results indicated that the expression of the LHR was elevated at pH 8.0 when CpxR was absent. The LHR did not improve survival of E. coli MG1655 at extreme alkaline $\mathrm{pH}(\mathrm{pH}=11.0$ to 11.2) but improved survival at $\mathrm{pH} 11.0$ in the presence of chlorine. Therefore, we conclude that the LHR confers resistance to extreme alkaline $\mathrm{pH}$ in the presence of oxidizing agents. Resistance to alkaline $\mathrm{pH}$ is regulated by an endogenous mechanism, including the Cpx envelope stress response, whereas the LHR confers resistance to extreme alkaline $\mathrm{pH}$ only in the presence of additional stress such as chlorine.
\end{abstract}

Keywords: Escherichia coli; locus of heat resistance; Cpx two-component regulatory system; alkaline $\mathrm{pH}$ response

\section{Introduction}

Escherichia coli are commensals in the intestine of humans and animals, but the species also includes pathogenic strains that cause infections of the gastrointestinal and urinary tracts [1,2]. Food contamination by pathogenic E. coli may occur at any step of the farmto-fork continuum and is a significant contributor to foodborne disease [3,4]. In food processing plants, alkaline-chlorinated sanitizers are used to sanitize food contact surfaces [5]. The chlorine and alkaline treatments function through synergistic mechanisms. Hypochlorous acid $(\mathrm{HOCl})$, the active component of chlorine, oxidizes cellular components and permeabilizes the cytoplasmic membrane [6-8]. Extreme alkaline $\mathrm{pH}$ also denatures proteins and results in membrane permeabilization [9]. Mechanisms that allow strains of E. coli to resist chlorine include the locus of heat resistance (LHR) [10,11].

The LHR is a genomic island flanked by mobile genetic elements, which transfers among diverse species of Enterobacteriaceae, including opportunistic human pathogens in the genera Cronobacter, Klebsiella and Enterobacter [12,13]. The most frequent LHR variant in E. coli, including E. coli AW1.7, is the $15 \mathrm{~kb}$ LHR1, but other sequence variants with insertions or deletions, including the $19 \mathrm{~kb}$ LHR2, were also described [12,13]. Collectively, genes encoded by the LHR confer resistance to heat, chlorine and oxidative stress by reducing protein aggregation, protein oxidation and the oxidation of membrane lipids $[10,14-16]$. 
Proteomic analysis demonstrated that 11 of the 16 putative open reading frames of the LHR1 are expressed; highly expressed proteins include $\mathrm{sHsp20,} \mathrm{ClpK}_{\mathrm{GI}}, \mathrm{sHsp}_{\mathrm{GI}}, \mathrm{YfdX}_{\mathrm{GI}}$ and YfdX2 [16]. The small heat shock protein sHsps and disaggregase ClpK prevent the aggregation of misfolded proteins or disaggregate and refold denatured proteins [17,18]. YfdX has a predicted signal peptide in the N-terminus, is likely localized in the periplasmic space, demonstrating chaperone-like activity [19], and is induced by the EvgA response regulator [20]. The LHR also encodes for $\mathrm{KefB}_{\mathrm{GI}}, \mathrm{a} \mathrm{Na}^{+} / \mathrm{H}^{+}$antiporter that may function to maintain a polarized membrane in alkaline conditions [14] and thus may contribute to alkaline resistance, i.e., growth at alkaline $\mathrm{pH}$, or alkaline tolerance, i.e., improved survival after lethal challenge with alkaline [21,22]; however, the role of $\mathrm{KefB}_{\mathrm{GI}}$ in alkaline tolerance or alkaline resistance has not been verified experimentally.

Although close homologs of several highly expressed LHR-encoded proteins have been shown or implied to function on the bacterial cell envelope, the ability of the LHR to mitigate envelope stress remains to be investigated $[16,19,23]$. In E. coli, homeostasis of the cell envelope in response to perturbations is provided by the envelope stress responses. $\mathrm{Cpx}$, a two-component regulatory system consisting of CpxA, a membrane-associated sensor kinase and the response regulator $\mathrm{CpxR}$, is a widely conserved regulator of the envelope stress response in Gram-negative bacteria [24,25]. The most commonly accepted model suggests that the Cpx system detects misfolded proteins in the periplasm and maintains the integrity of the cytoplasmic membrane [26,27]. Therefore, Cpx is a suitable reporter system to monitor putative protective effects of LHR-encoded proteins on the cell envelope. In addition, the functional overlap between the LHR and Cpx response also suggests the possibility of cross-talk between these two mechanisms of stress resistance. This study therefore aimed to determine whether the LHR impacts the expression of the Cpx regulon, whether CpxR regulates the expression of the genes encoded by the LHR, and to compare the role of CpxR and the LHR on the growth and survival of E. coli at alkaline $\mathrm{pH}$.

\section{Materials and Methods}

\subsection{Bacterial Strains, Plasmids and Growth Conditions}

Strains and plasmids used in this study are listed in Table 1. Unless otherwise stated, Escherichia coli strains were grown at $37^{\circ} \mathrm{C}$ on Luria-Bertani (LB) plates or in LB broth with antibiotics added when necessary.

Table 1. Bacterial strains and plasmids used in this study.

\begin{tabular}{|c|c|c|}
\hline Strain/Plasmid & Description & Reference \\
\hline E. coli MG1655 & E. coli $\mathrm{K}-12$ derivatives & \\
\hline E. coli MG1655 lacZ::LHR & $\begin{array}{l}\text { Full-length LHR with its promoter inserted into } \\
\text { MG1655 lacZ }\end{array}$ & This study \\
\hline E. coli MG1655 $\Delta c p x R::$ Kan & $\begin{array}{l}\text { E. coli MG1655 with chromosomal cpxR replaced } \\
\text { by the kanamycin resistance cassette }\end{array}$ & This study \\
\hline $\begin{array}{l}\text { E. coli MG1655 lacZ::LHR } \\
\qquad c p x R:: \text { Kan }\end{array}$ & $\begin{array}{c}\text { E. coli MG1655 lacZ::LHR with chromosomal } \\
\text { cpxR replaced by the kanamycin resistance } \\
\text { cassette }\end{array}$ & This study \\
\hline $\begin{array}{l}\text { E. coli MG1655 lacZ::LHR } \\
\qquad k e f B_{G I}:: F R T\end{array}$ & $\begin{array}{l}\text { E. coli MG1655 lacZ::LHR with LHR kefB }{ }_{G I} \\
\text { replaced by the FRT scar site }\end{array}$ & This study \\
\hline $\begin{array}{l}\text { E. coli MG1655 lacZ::LHR } \\
\Delta \text { kefB }_{G I}: \text { FRT } \Delta c p x R:: \text { Kan }\end{array}$ & $\begin{array}{l}\text { E. coli MG1655 lacZ::LHR with LHR kefB } B_{G I} \\
\text { replaced by the FRT scar site and chromosomal } \\
\text { cpxR replaced by the kanamycin resistance } \\
\text { cassette }\end{array}$ & This study \\
\hline $\begin{array}{c}\text { E. coli MG1655 lacZ::LHR } \\
\text { \evgA::Kan }\end{array}$ & $\begin{array}{l}\text { E. coli MG1655 with chromosomal evgA replaced } \\
\text { by the kanamycin resistance cassette }\end{array}$ & This study \\
\hline pJW15 & $\begin{array}{l}\text { Promoterless luminescence reporter plasmid } \\
\text { containing } \operatorname{lu} x C D A B E \text { operon, } \text { ori }_{p 15 A} ; \mathrm{Kan}^{\mathrm{r}}\end{array}$ & [28] \\
\hline pJW25 & pJW15 plasmid containing cpxP promoter; $\operatorname{Kan}^{\mathrm{r}}$ & [28] \\
\hline pLHR & Low-copy plasmid containing the LHR & [12] \\
\hline
\end{tabular}


Table 1. Cont.

\begin{tabular}{ccc}
\hline Strain/Plasmid & Description & Reference \\
\hline pKDsg-lacZ & Plasmid containing crispr-targeting sequences & This Study \\
for lacZ & Plasmid with cas9 expressed under control of the & P29] \\
pCP20 & $\begin{array}{c}\text { P } \text { TET promoter } \\
\text { Plasmid enabling Flp-catalyzed excision of the } \\
\text { antibiotic resistance gene }\end{array}$ & {$[30]$} \\
\hline
\end{tabular}

\subsection{Construction of Derivatives of E. coli MG1655}

The strain E. coli MG1655 used in this study is an E. coli K-12 derivative. The strain MG1655 lacZ::LHR with a chromosomal integration of the LHR was constructed by the Scarless Cas9-Assisted Recombineering system [29]. pLHR was digested by the DraI enzyme (Thermo Fisher, Mississauga, ON, Canada) to linearize the pLHR plasmid, which contains the LHR fragment flanked by parts of the lac $Z$ gene [12]. The $\lambda$-Red was preinduced in an MG1655 strain containing both pKDsg-lacZ and pCas9cr4 followed by electroporation of the LHR fragments. After recovery, the culture was grown overnight with chloramphenicol (34 mg/L), spectinomycin (50 mg/L) and anhydrotetracycline $(100 \mu \mathrm{g} / \mathrm{L})$. The overnight culture was treated at $60^{\circ} \mathrm{C}$ for $5 \mathrm{~min}$ and plated on LB agar containing IPTG (isopropyl $\beta$-d-1-thiogalactopyranoside, $0.2 \mathrm{mM})$ and X-gal $(40 \mathrm{~g} / \mathrm{L})$. White colonies were screened with LHR-16-F/lacZ-upstream, LHR-2-R/lacZ-downstream and yfdX1-check-F/R primers (Table 2) to identify the target mutant followed by plasmid loss.

MG1655 lacZ::LHR $\Delta k e f B_{G I}$ was constructed using the $\lambda$-Red system [31]. The donor DNA was PCR generated with a chloramphenicol cassette flanked by sequences up- and downstream of $k e f B_{G I}$. pKD46 was transformed into MG1655 lacZ::LHR, and $\lambda$-Red was induced to facilitate the genomic integration of donor DNA. The mutant was picked from plates containing chloramphenicol $(25 \mathrm{mg} / \mathrm{L})$ and checked with primers listed in Table 2. pCP20 was used to remove the chloramphenicol cassette [31].

Mutant constructions of $\triangle c p x R$ and $\triangle e v g A$ were done by P1 transduction based on the previous description [32]. Briefly, the P1 vir phage was first grown on the donor KEIO collection single-gene knockout strain, and the resulting P1 lysate was used to infect the recipient strains [33]. The potential mutants were selected on LB plates containing lowconcentration kanamycin $(25 \mathrm{mg} / \mathrm{L})$ followed by purification with a high concentration (50 mg/L). Mutations were confirmed by PCR using the primers listed in Table 2.

Table 2. Primers used in this study.

\begin{tabular}{|c|c|c|}
\hline Primer & Sequence $\left(5^{\prime}-3^{\prime}\right)$ & Ref. $^{\text {a) }}$ \\
\hline \multirow{2}{*}{ sgRNA-lacZ-F } & GGCCAGTGAATCCGTAATCAG & \\
\hline & TTTTAGAGCTAGAAATAGCAAG & \\
\hline \multirow{2}{*}{ sgRNA-lacZ-R } & TGATTACGGATTCACTGGCCG & \\
\hline & TGCTCAGTATCTCTATCACTGA & \\
\hline Targeting sequence & GGCCAGTGAATCCGTAATCA & \\
\hline LHR-16-F & CGGTATCGCCGTCGACGACG & \\
\hline lacZ-upstream & GCTGTTGCCCGTCTCACTGG & \\
\hline LHR-2-R & GCCGGAATTTCCCCGTGTGC & \\
\hline lacZ-downstream & GGACGACGACAGTATCGGCC & \\
\hline yfdX1-check-F & TCGGTAAAGAAAGCGGTCAAG & \\
\hline yfdX1-check-R & CATCGGAAGGTTGTCGGTTT & \\
\hline \multirow{2}{*}{ kefB-P2 } & CATCGTGCGCTGGACGTCGACGCAAGTGGG & \\
\hline & ACGCTGACCGATGGGAATTAGCCATGGTCC & \\
\hline \multirow{2}{*}{ kefB-P1 } & TGGTCACGTAAGACCTGAAATGGGTTAAGG & \\
\hline & CGTGTTGATTGTGTAGGCTGGAGCTGCTTC & \\
\hline kefB-check-F & TTGCTGGGGTATCTCTCTGT & \\
\hline kefB-check-R & CAGCCACATCAATAGCAGGA & \\
\hline$c p x R \mathrm{~F}$ & CTATGCGCATCATTTGCTCC & \\
\hline cpxR R & CATGCTGCTCAATCATCAGC & \\
\hline
\end{tabular}


Table 2. Cont.

\begin{tabular}{|c|c|c|}
\hline Primer & Sequence $\left(5^{\prime}-3^{\prime}\right)$ & Ref. a) \\
\hline k1 & CAGTCATAGCCGAATAGCCT & [30] \\
\hline $\operatorname{evg} A \mathrm{~F}$ & GACGCCTTATGTCTGTATTAC & \\
\hline $\operatorname{evg} A \mathrm{R}$ & GTTGCTGCGAATCGGTATG & \\
\hline Orf1-F & GGTGATTTTCACGCTCGATG & \\
\hline Orf1-R & TCGGATGACTTCTGCTGTTC & \\
\hline ORF8-F & TCGGTAAAGAAAGCGGTCAAG & [34] \\
\hline ORF8-R & CATCGGAAGGTTGTCGGTTT & [34] \\
\hline Orf13-F & TTGCTGGGGTATCTCTCTGT & \\
\hline Orf13-R & CAGCCACATCAATAGCAGGA & \\
\hline gapA-F & GTTGACCTGACCGTTCGTCT & [35] \\
\hline gapA-R & ACGTCATCTTCGGTGTAGCC & [35] \\
\hline
\end{tabular}

a) Primers were designed in this study if a reference is not provided.

\subsection{Phylogenetic Tree of the CpxR Response Regulator}

To construct a phylogenetic tree, the amino acid sequence of CpxR from E. coli MG1655 was used as the query to blast against the National Center for Biotechnology Information (NCBI) non-redundant reference proteins database in 15 May 2020. A coverage of $70 \%$ and identity of $60 \%$ were used as the cut-off values. The tree was generated with one sequence from each species of the family Enterobacteriaceae with the sequence from Vibrio cholerae as outgroup. The sequences were aligned by MUSCLE (https://www.ebi.ac.uk/Tools/msa/ muscle/; accessed on 4 June 2020). The tree was constructed using maximum likelihood by MEGAX [36] (v10.1.8) and viewed by iTol (https:/ / itol.embl.de; accessed on 5 June 2020).

\subsection{Determination of the Cpx Pathway by Bioluminescence Assay}

The Cpx response was determined with a luminescent reporter assay [37]. Single colonies of MG1655 and MG1655 lacZ::LHR carrying the low-copy-number plasmids pJW15 or pJW25 were inoculated overnight in LB broth and subcultured 1:100 into $5 \mathrm{~mL}$ of LB with $25 \mathrm{mg} / \mathrm{L}$ kanamycin and incubated with agitation at $200 \mathrm{rpm}$. Different from all other assays, which used an incubation temperature of $37^{\circ} \mathrm{C}$, all cultures used for the lux assay were incubated at $30^{\circ} \mathrm{C}$ because the optimal temperature for luciferase is $28^{\circ} \mathrm{C}$. The $\mathrm{Cpx}$ activities were induced in different conditions. Cultures growing exponentially at $30{ }^{\circ} \mathrm{C}$ were harvested at an $\mathrm{OD}_{600 \mathrm{~nm}}$ of 0.4 ; stationary-phase cultures were harvested at $\mathrm{OD}_{600 \mathrm{~nm}}$ of 1.0. To determine the influence of aeration on Cpx activity, half the volume of each subculture was cultivated in aerobic conditions; the other aliquot was incubated in a $2 \mathrm{~mL}$ microcentrifuge tube that was closed and additionally sealed with parafilm to reduce diffusion of oxygen. The subcultures were incubated together and incubated at $30{ }^{\circ} \mathrm{C}$ $200 \mathrm{rpm}$ for $18 \mathrm{~h}$ before measurements. To determine the impact of alkaline $\mathrm{pH}$, cells from $2 \mathrm{~mL}$ culture were harvested and resuspended in $2 \mathrm{~mL}$ of LB with $\mathrm{pH}$ adjusted to 7.0, 8.0, 8.5 and 9.0 by adding $\mathrm{HCl}$ or $\mathrm{NaOH}$. The bacteria were induced for $1 \mathrm{~h}$ in alkaline conditions before readings were taken. For other experiments, exponentially growing bacteria were induced for $2 \mathrm{~h}$ with the following inducing reagents (final concentration): $1 \mathrm{mM} \mathrm{ZnSO}_{4}$, $1 \mathrm{mM} \mathrm{CuSO}_{4}$ and $6 \mathrm{mM}$ 2-phenylethanol (Sigma-Aldrich, Oakville, ON, Canada). Cultures without an inducing agent served as a reference. Luminescence and optical density at $600 \mathrm{~nm}$ of a $200 \mu \mathrm{L}$ aliquot were measured in 96-well clear-bottom white plates (ThermoFisher) by plate readers (luminescence: Victor X4, Perkin Elmer, Waltham, MS, USA; OD 600 : Varioskan Flash, Thermo Fisher). The normalized luminescence value was calculated by standardizing the luminescence intensity to the $\mathrm{OD}_{600}$. The values obtained from the strains with pJW15 were used as a blank and subtracted from the readings acquired from the same strains containing pJW25. The fold change was calculated by dividing values for the induced conditions by the values for the uninduced condition of the same strain. 
Bioluminescence assays were performed in triplicate independent experiments that were analyzed in duplicate.

\subsection{Measurement of LHR Gene Expression by RT-qPCR}

The expression of genes encoded by the LHR was quantified by RT-qPCR essentially as previously described [10]. Overnight cultures were subcultured 1:100 in LB buffered to a $\mathrm{pH}$ of 7.1 or 8.2 by the addition of Tris and phosphate (50 $\mathrm{mM}$ each) and were grown to an $\mathrm{OD}_{600 \mathrm{~nm}}$ of 0.5 at $37{ }^{\circ} \mathrm{C}$ with $200 \mathrm{rpm}$ agitation. The cells were harvested, and RNA isolation was done using RNAprotect bacteria reagent and the RNAeasy mini kit (Qiagen, Hilden, Germany). The gDNA was removed by RQ1 RNase-Free DNase (Promega, Madison, WI, USA) and the reverse transcription of the RNA to CDNA was done with the QuantiTect ${ }^{\circledR}$ reverse transcription kit (Qiagen). QuantiTect SYBR ${ }^{\circledR}$ Green PCR Kits (Qiagen) and the 7500 fast real-time PCR system (Applied Biosystems, Waltham, MS, USA) were used to measure the LHR expression with the primers targeting orf1, yfdX $1_{G I}$ and kefB $B_{G I}$ (Table 2). The glyceraldehyde-3-phosphate dehydrogenase A gene (gapA) was used as the house-keeping gene; DNase-digested RNA and water served as negative controls. The $\log _{2}$-normalized relative gene expression level was calculated by the $\Delta \Delta C_{\mathrm{T}}$ method [10] by calculating gene expression by MG1655 lacZ::LHR $\Delta c p x$ or MG1655 lacZ::LHR $\Delta e v g A$ relative to the expression of the same gene by MG1655 lacZ::LHR grown at the same $\mathrm{pH}$. Data shown are from three independent experiments that were analyzed in duplicate.

\subsection{Determination of the Growth Rates}

Tris-phosphate (50 mM each)-buffered LB was prepared at two different $\mathrm{pH}$ levels each at two different osmolarity levels and filter sterilized. Unless otherwise noted, LB media contained $10 \mathrm{~g} / \mathrm{L} \mathrm{NaCl}$. The low-salt media was made by adding $10 \mathrm{~g}$ of tryptone, $5 \mathrm{~g}$ of yeast extract, $4.1 \mathrm{~g}$ of $\mathrm{NaCl}, 6.1 \mathrm{~g}$ of trizma base and $7.1 \mathrm{~g}$ of $\mathrm{Na}_{2} \mathrm{HPO}_{4}$ (Sigma-Aldrich) to $1 \mathrm{~L}$ of distilled water with a final $\mathrm{pH}$ of 6.5 and 10.0. To obtain the working media, LB broth at each $\mathrm{pH}$ and osmolarity were mixed in different ratios in clear-bottom 96-well plates (Corning, USA) to achieve a $\mathrm{pH}$ gradient. The resulting $\mathrm{pH}$ in media containing the high $\mathrm{pH}$ and low-pH media in different ratios was measured with a glass electrode. The bacteria were grown for $24 \mathrm{~h}$ in $5 \mathrm{~mL}$ of LB broth and subcultured 1:1000 in a final volume of $155 \mu \mathrm{L}$. $\mathrm{OD}_{600 \mathrm{~nm}}$ was measured every $30 \mathrm{~min}$ for $16 \mathrm{~h}$ by a microtiter plate reader at $37^{\circ} \mathrm{C}$ with a rotation diameter of $6 \mathrm{~mm} / \mathrm{s}$. Growth rates were calculated by fitting experimental data to the logistic growth curve [22] in SigmaPlot (version 12.5, Systat Software Inc., San Jose, CA, USA) with the data from three biological replicates.

\subsection{Determination of the Tolerance to Extreme Alkaline $p H$ with or without Chlorine Treatment}

To determine the bacterial tolerance to extreme alkaline $\mathrm{pH}$, filter-sterilized carbonatebicarbonate $(50 \mathrm{mM})$-buffered LB was prepared by adding $0.525 \mathrm{~g}$ of sodium bicarbonate and $4.637 \mathrm{~g}$ of sodium carbonate (anhydrous) into $1 \mathrm{~L}$ of LB broth with the final $\mathrm{pH}$ of 11.2. Cultures were grown overnight in LB at $37^{\circ} \mathrm{C}$ at $200 \mathrm{rpm}$ agitation; cells from $500 \mu \mathrm{L}$ of culture were pelleted by centrifugation and resuspended in $500 \mu \mathrm{L}$ of carbonatebicarbonate-buffered LB for $5 \mathrm{~min}$. Sterile water $\left(4.5 \mathrm{~mL}\right.$ of $18 \mathrm{M}^{\prime} \Omega$ water) was added to the mixture and the after-treatment $\mathrm{pH}$ was measured. Alkaline $\mathrm{pH}$ tolerance with the addition of chlorine was determined by resuspending the bacterial pellet the same volume of filter-sterilized pH $11 \mathrm{LB}$ including $10 \mathrm{mM} \mathrm{NaClO}$ (5\% w/w, Sigma-Aldrich). After $5 \mathrm{~min}$, cells were harvested by centrifugation and resuspended in LB broth. The viable cell count was determined by serial dilution and surface plating using LB broth and agar plate for both treated and untreated samples. The values were log-transformed and the reduction of cell count was calculated as $\log \left(\mathrm{N}_{0} / \mathrm{N}\right)$. Data are from three independent experiments performed with technical repeats. 


\subsection{Statistical Analysis}

Statistical analyses were performed with RStudio (version 1.2.1335, R Core Team, Vienna, Austria). Technical repeats were averaged without carry-over of the error term prior to statistical analysis. Differences among Cpx activities and gene expression were determined by a one-sample, two-tailed Student's $t$-test $(p<0.05)$. Differences among cell count reductions were determined by one-way ANOVA followed by Tukey's HSD $(p<0.05)$.

\section{Results}

\subsection{Coexistence of the CpxR Response Regulator and the LHR}

In the Enterobacterales, the LHR has to date only been identified in the family Enterobacteriaceae and the genus Yersinia [12]. To provide an initial assessment of cross-talk between CpxR and LHR, we determined whether genomes of those species that encode for the LHR also encode for CpxR. The CpxR response regulator is present in all species possessing the LHR, except Citrobacter braakii, indicating that interaction between the Cpx pathway and LHR is feasible (Figure 1).

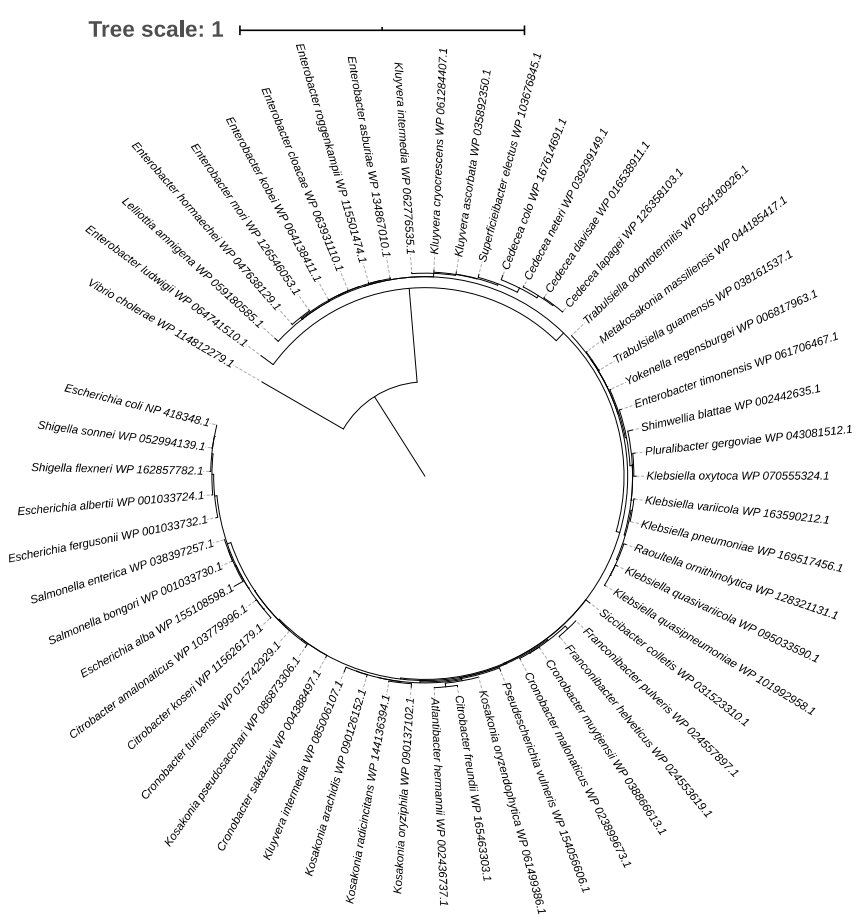

Figure 1. A phylogenetic tree showing the distribution of the CpxR response regulator in family Enterobacteriaceae with Vibrio cholerae as the outgroup.

\subsection{The Presence of the LHR Does Not Alter Cpx Pathway Activity}

To determine whether LHR plays a role in maintaining protein homeostasis in the bacterial periplasm or inner membrane integrity, we assessed the Cpx pathway activity in E. coli MG1655 and its derivative carrying the LHR, MG1655 lacZ::LHR, under various stress conditions. The $\mathrm{Cpx}$ response is activated by the stationary phase, aerobic conditions, elevated $\mathrm{pH}$ and the presence of zinc, copper and ethanol [27,38-43]. As a member of the Cpx regulon, cpxP is one of the most upregulated genes when Cpx is activated [40]. Therefore, pJW15, the promoterless vector control carrying lux operon and its derivative pJW25 with cpxP'-lux reporter were used to monitor Cpx activity. The Cpx pathway was highly upregulated after induction relative to the reference conditions in both $E$. coli MG1655 and E. coli MG1655 lacZ::LHR (Figure 2); however, this induction was not altered $(p>0.05)$ by the presence of the LHR (Figure 2). 


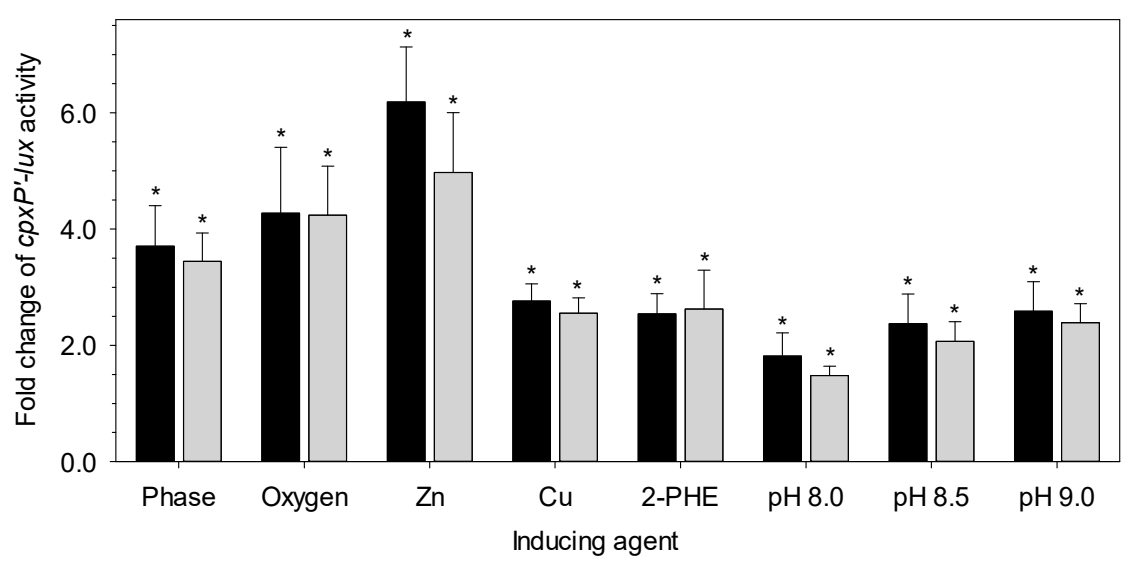

Figure 2. The Cpx responses in E. coli MG1655 (black bars) and MG1655 lacZ::LHR (gray bars) under different conditions. The fold change of $c p x P^{\prime}-l u x$ activity was calculated relative to the reference conditions as follows: stationary phase vs. log phase (reference); aerobic vs. anaerobic incubation (reference); $1 \mathrm{mM} Z \mathrm{Zn}$ vs. no addition (reference); $1 \mathrm{mM} \mathrm{Cu}$ vs. no addition (reference); $6 \mathrm{mM}$ phenylethanol (2-PHE) vs. no addition (reference), $\mathrm{pH}$ 8.0, 8.5 and 9.0 vs. 7.0 (reference for all three $\mathrm{pH}$ values). An asterisk indicates a significant difference between the experimental conditions and the respective reference conditions $(p<0.05)$; however, $c p x P^{\prime}-l u x$ activity was not altered $(p>0.05)$ by the presence of the locus of heat resistance (LHR). The bars represent the mean values with standard deviations as the error bars for three independent experiments.

\subsection{LHR Transcriptional Level Is Affected by CpxR but Not by the EvgA Response Regulator at} Alkaline $\mathrm{pH}$

To determine whether the expression of the LHR is directly or indirectly dependent on the EvgA or CpxR response regulators, the mRNA of three fragments of the LHR, orf1, yfdX1 $1_{G I}$ and $k e f B_{G I}$ [14], were quantified by RT-qPCR in E. coli MG1655 lacZ::LHR, MG1655 lacZ::LHR $\Delta c p x R$ and MG1655 lacZ::LHR $\Delta e v g A$. At pH 7.1, the difference in expression of the LHR among the strains was smaller than the experimental error that is generally observed for mRNA quantification with the $\Delta \Delta \mathrm{C}_{\mathrm{T}}$ method (Figure 3A). At a pH of 8.0, the lack of functional EvgA did not affect LHR transcription; however, deletion of $c p x R$ increased the expression of orf1, yfdX $1_{G I}$ and $k e f B_{G I}$ (Figure 3B). Results indicate that alkaline conditions activate LHR expression in the absence of the CpxR response regulator.

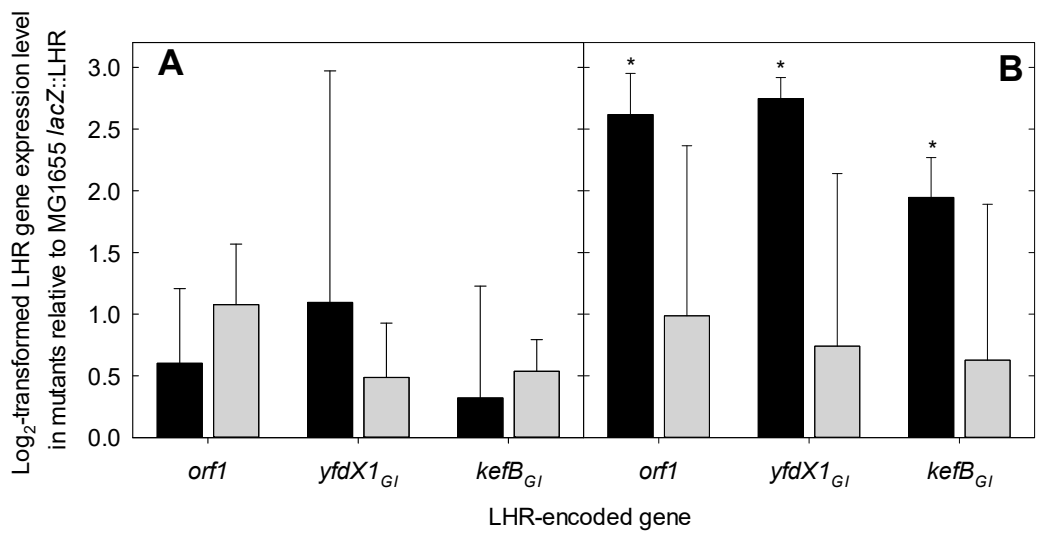

Figure 3. The expression level of the LHR in E. coli MG1655 lacZ::LHR with either cpxR (black bars) or $\operatorname{evg} A$ knocked out (gray bars) relative to the expression in MG1655 lacZ::LHR. (A) pH = 7.1; (B) pH $=8.0$. Expression of the LHR was measured by quantification of mRNA of the genes orf1, yfdX1 $1_{G I}$ and $k e f B_{G I}$ with RT-qPCR by using MG1655 lacZ::LHR as reference. Asterisks indicate means that were significantly different from the respective reference condition $(p<0.05)$. The bars represent the mean values with standard deviations as the error bars for three independent experiments. 


\subsection{Cpx but Not the LHR Is Necessary for Growth in Alkaline $p H$}

The Cpx response has been implicated in elevated $\mathrm{pH}$ adaptation, and the disruption of cpxR in E. coli impaired growth under alkaline conditions [40]. KefB is a glutathioneregulated potassium/proton antiporter-protecting bacteria from electrophile toxicity [44]. Therefore, to determine the role of the LHR in resistance to alkaline $\mathrm{pH}$ and the contribution of kefB $B_{G I}$, we assessed the growth rates of E. coli MG1655, MG1655 lacZ::LHR, MG1655 $\Delta c p x R$, MG1655 lacZ::LHR $\triangle c p x R$ and MG1655 lacZ::LHR $\triangle k e f B_{G I}$ in buffered LB at pH 6.9 to 9.2. The growth rates of E. coli MG1655, MG1655 lacZ::LHR and MG1655 lacZ::LHR $\Delta k e f B_{G I}$ at neutral or alkaline were not different (Figure 4). The growth rates of $\Delta c p x R$ LHR-negative and -positive strains were comparable to the strains with a functional CpxR at $\mathrm{pH}$ values below 8.0. At $\mathrm{pH} 8.0$ and above, deletion of $\operatorname{cpxR}$ reduced growth, and the maximum $\mathrm{pH}$ value of growth was reduced from 9.2 to 8.2, irrespective of the presence of the LHR (Figure 4). Comparable results were obtained in media containing 0.4 or $1 \% \mathrm{NaCl}$ (Figure 4). Therefore, a functional Cpx pathway but not the LHR is required for bacterial growth at mild alkaline $\mathrm{pH}$.

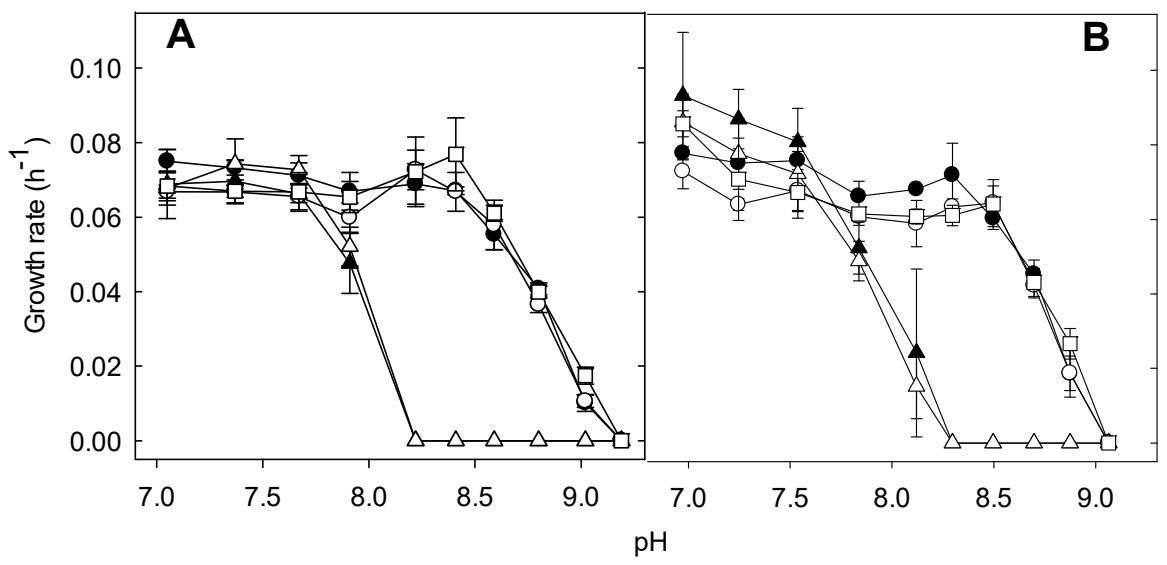

Figure 4. The growth rates of E. coli MG1655 and MG1655 lacZ::LHR and gene knockout derivative strains at $\mathrm{pH}$ values ranging from 6.9 to 9.2. (A) Strains were incubated in Tris-phosphate $(50 \mathrm{mM}$ each of Tris and phosphate)-buffered Luria-Bertani (LB) with $0.41 \% \mathrm{NaCl}$. (B) Strains were incubated in Tris-phosphate (50 mM each of Tris and phosphate)-buffered LB broth ( $1 \% \mathrm{NaCl}$ ). All strains were subcultured at 1:1000 from overnight cultures and incubated at $37^{\circ} \mathrm{C}$ for $16 \mathrm{~h}$. (•) MG1655, (○) MG1655 lacZ::LHR, (ム) MG1655 $\Delta c p x R,(\Delta)$ MG1655 lacZ::LHR $\Delta c p x R$, ( $\square)$ MG1655 lacZ::LHR $\Delta k e f B_{G I}$. Data are shown as mean \pm standard deviation of three independent experiments.

\subsection{LHR Improves Bacterial Survival to Extreme Alkaline $p H$ in the Presence of Chlorine}

The LHR protects E. coli against lethal challenges with chlorine [10]; therefore, the role of CpxR and the LHR was explored by determination of the survival of E. coli MG1655, MG1655 lacZ::LHR, MG1655 $\Delta c p x R$, MG1655 lacZ::LHR $\Delta c p x R$, MG1655 lacZ::LHR $\Delta k e f B_{G I}$ and MG1655 lacZ::LHR $\Delta c p x R \Delta k e f B_{G I}$ under extreme alkaline conditions in the absence or presence of chlorine. All strains survived challenge at $\mathrm{pH} 11.0$ for $5 \mathrm{~min}$ with a reduction of viable cell counts of less than $1 \log (\mathrm{cfu} / \mathrm{mL})$; challenge at $\mathrm{pH} 11.3$ reduced cell counts of all strains to levels below the detection limit (Figure S1). When treated with carbonate-bicarbonate-buffered LB at $\mathrm{pH} 11.2$, the viable cell counts of all strains were reduced by about $1-2 \log (\mathrm{cfu} / \mathrm{mL}$ ) (Figure 5A). E. coli MG1655 and its cpxR null derivative demonstrated a similarly high level of sensitivity to $\mathrm{pH} 11.0$ with the addition of chlorine (Figure 5). The wild-type strain harboring LHR was more tolerant $(p<0.05)$ to alkaline conditions in the presence of chlorine; however, deletion of cpxR or kefB $B_{G I}$ or both diminished tolerance (Figure 5). In summary, the LHR improves bacterial survival under extreme alkaline $\mathrm{pH}$ only in the presence of chlorine, and the contribution of the LHR depends on the presence of $c p x R$ and $k e f B_{G I}$. 


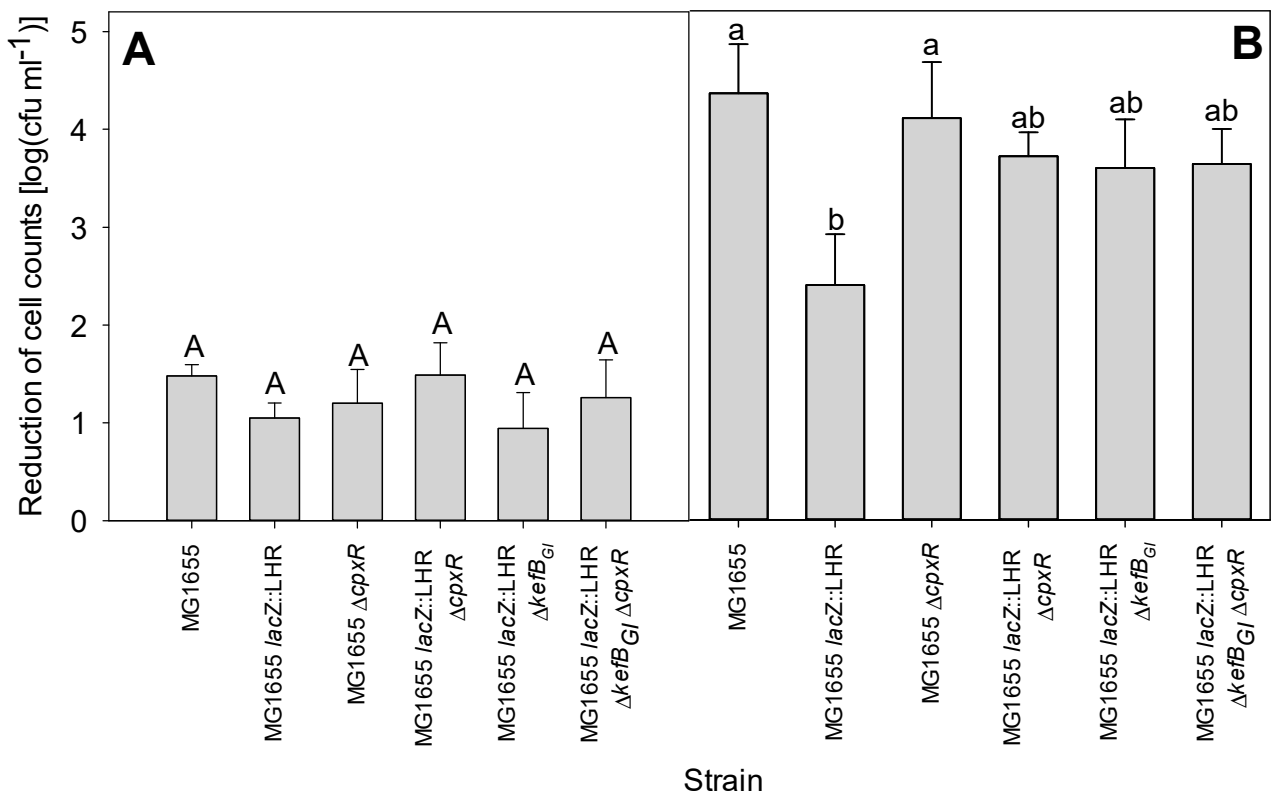

Figure 5. Reduction of cell counts of E. coli MG1655 and MG1655 lacZ::LHR and gene knockout derivative strains under different stress conditions. (A) Extreme alkaline $\mathrm{pH}$ killing: the overnight cultures of all the tested strains were treated with $50 \mathrm{mM}$ carbonate-bicarbonate-buffered LB under $\mathrm{pH} 11.2$ condition for $5 \mathrm{~min}$. (B) Extreme alkaline pH plus chlorine killing: the overnight cultures of all the tested strains were treated at $\mathrm{pH} 11.0$ with $10 \mathrm{mM} \mathrm{NaClO}$ condition for $5 \mathrm{~min}$. Bars in each panel differ significantly $(p<0.05)$ if they do not share a common capital (A) or lowercase (B) letter. The bars represent the mean values with standard deviations as the error bars for three independent experiments.

\section{Discussion}

We hypothesized that proteins encoded by the LHR contribute to cell envelope homeostasis, thereby promoting bacterial survival under various stress conditions and reducing gene induction by the Cxp and EvgAS systems. EvgAS is a two-component regulatory system that is related to osmotic adaptation, as well as acid and antibiotic resistance, by regulating the gene encoding chaperone-like proteins and drug transporters [20,45]. The expression of the core-genome $y f d X$ gene in $E$. coli is significantly induced by overexpression of the EvgA response regulator [20], and the p2 promoter of the LHR was previously reported to be induced by EvgA [14]. YfdX demonstrates chaperone-like activity preventing protein aggregation and exhibits a $\mathrm{pH}$-dependent stoichiometric conversion between dimeric and tetrameric states at $\mathrm{pH} 10.0$ and 7.5, respectively, which suggests its possible function involved in $\mathrm{pH}$ adaptation $[19,46]$. A deletion of $y f d X$ was complemented by overexpression of the periplasmic chaperone HdeA, supporting the above prediction [47]. $\mathrm{YfdX} 1_{\mathrm{GI}}$ encoded by the LHR is controlled by a different promoter but also includes a predicted Sec-dependent protein secretion signal peptide at its N-terminus (SignalP, v5.0, Denmark [48]), suggesting its involvement in envelope protein homeostasis. Results of the present study contrast a previous report that expression from the LHR-promoter $\mathrm{p} 2$ is dependent on EvgA [14]. The p2 promoter is directly upstream of orf1; however, orf1 expression levels were not dependent on EvgA (Figure 3). The role of EvgA in LHR-mediated stress resistance thus requires further investigation.

The LHR also confers significant chlorine resistance [10]. Chlorine non-selectively oxidizes cellular components, including proteins and nucleotides, and also increases the permeability of the cytoplasmic membrane [6-8]. Protein denaturation and aggregation in both the cytoplasm and the periplasm or membrane leakage induced by chlorine treatments can eventually lead to cell death. Combined, these observations suggest that the LHR may play a role in envelope protein homeostasis. However, our results indicate that the LHR does not mitigate the impact of the alkaline conditions on those components that activate the Cpx response (Figure 4). Expression of the LHR in E. coli, however, is affected 
by CpxR (Figure 3). The converse does not seem to be true since the presence or absence of the LHR did not impact expression of a Cpx-regulated reporter gene (Figure 2). The LHR reduces the oxidation of membrane lipids [10], and so the present study thus suggests that oxidation of membrane lipids is not an inducing signal for the Cpx pathway.

Bioinformatic analyses demonstrated that the CpxR response regulator is present in Enterobacteriaceae, including all of those species that include strains that possess the LHR except Citrobacter braakii (Figure 1). LHR-encoded proteins are among the most highly expressed proteins in E. coli [16]. Deletion of the CpxR response regulator did not alter LHR expression at neutral $\mathrm{pH}$ but increased its transcription level at $\mathrm{pH}$ 8.0. The $\mathrm{Cpx}$ pathway responds to elevated extracellular $\mathrm{pH}$. Although the growth of the $c p x R$ null mutant strain was comparable to the wild-type strain at neutral $\mathrm{pH}$, its growth was impaired at alkaline conditions and failed to grow at $\mathrm{pH} 9.0$ to $9.2[37,40]$. These results indicate the possibility that the LHR may confer tolerance to lethal conditions at alkaline $\mathrm{pH}$ and that the $\mathrm{Cpx}$ response may act as a "switch" that shifts bacterial adaptation from mild to lethal stress: Under moderate stress conditions, the activation of the Cpx pathway mitigates periplasmic stress and maintains the LHR expression at a low level to reduce fitness cost.

The adaptation to mild alkaline $\mathrm{pH}$ in mesophilic bacteria includes increasing acid production and ATP generation in the central carbon metabolism, enhanced expression of transporters and modification of membrane properties [21,49-55]. Among these, proton pumps and cation/proton antiporters are the main contributors to the ability of bacteria to maintain their internal $\mathrm{pH}$. This supports growth at an external $\mathrm{pH}$ of 5.5-9.0 while maintaining the cytoplasmic $\mathrm{pH}$ in the narrow range of 7.5-7.7 [21,56-62]. To date, very few reports demonstrate how mesophilic bacteria cope with extreme alkaline $\mathrm{pH}$. The LHR did not enhance resistance or tolerance of $E$. coli to alkaline $\mathrm{pH}$; however, the presence of both the Cpx pathway and the LHR enhanced the tolerance of E. coli to lethal challenge with alkaline $\mathrm{pH}$ in the presence of chlorine. Remarkably, although expression of LHR-encoded genes was derepressed in the $c p x R$ mutant of E. coli MG1655 during growth at alkaline $\mathrm{pH}$, the LHR-mediated resistance of cultures grown at neutral $\mathrm{pH}$ to chlorine at extreme alkaline conditions was dependent on a functioning Cpx system. The Cpx system, in conjunction with the $\sigma^{\mathrm{E}}$ and $\sigma^{32}$ responses, can sense and regulate gene expression in response to oxidative stress and high $\mathrm{pH}[26,40,63]$. In Salmonella enterica Typhimurium, CpxR is required to cope with bacterial oxidative damage [64]. Thus, envelope stress responses to alkaline $\mathrm{pH}$ and oxidative stress are often linked. Because the LHR only affects survival at alkaline $\mathrm{pH}$ in the presence of sodium hypochlorite, one possibility is that the function of the LHR in alkaline tolerance may require oxidative stress as the inducing signal. The E. coli genomes encode KefB, a potassium/proton antiporter that is repressed by glutathione (GSH). Glutathione-deficient mutants of E. coli exhibited a reduced cytoplasmic $\mathrm{pH}$ at 7.35 compared to the parent strain at $7.85[65,66]$. The Kef channels are regulated by their C-terminal NAD-binding domains containing a single binding site for GSH [67]. GSH stabilizes the interdomain association between two NAD-binding folds, therefore inhibiting Kef activity [67]. GSH, a predominant low-molecular-weight thiol in most Gram-negative bacteria, has been proposed to protect cells from oxidative damage. In vitro, $1 \mathrm{~mol} \mathrm{GSH}$ can react with 3.5 to $4.0 \mathrm{~mol} \mathrm{HOCl}$ [68]. In E. coli, the glutathione-deficient strain is twice as sensitive to killing by chlorine compared to its isogenic wild-type strain [69]. The lethal level of oxidative stress can dramatically increase the amount of intracellular glutathione disulfide (GSSG) and decrease the ratio of GSH/GSSG [70]. Therefore, the addition of chlorine consumes GSH in the bacterial cell, thereby activating $k e f B_{G I}$ and leading to cytoplasmic acidification, which protects bacteria [23]. Hence, the functional kefB $B_{G I}$ plays an essential and specific role in protecting the bacteria from the extreme alkaline condition in the presence of chlorine.

Notably, we also observed that bacterial survival and death under extreme alkaline conditions occurred within a very narrow $\mathrm{pH}$, which is opposite to its survival under extreme acidic $\mathrm{pH}$. Bacterial survival at low $\mathrm{pH}$ is well understood as microbes encounter acid environments in many situations, including low-pH foods and during gastrointestinal 
transit. E. coli withstands exposure to the extreme acidic condition-less than 1 log cell reduction at $\mathrm{pH} 2.5$ for at least $2 \mathrm{~h}$-as it possesses several amino-acid-dependent extreme acid resistance mechanisms [71-74]. The acid stress response maintains the bacterial intracellular $\mathrm{pH}$ through the amino-acid-dependent decarboxylase/antiporter activities and protects the proteins from acid damage by inducing the periplasmic chaperone expression $[73,75-78]$. However, how bacteria tolerate extreme alkaline $\mathrm{pH}$ is poorly documented in the literature. Therefore, our study more clearly defines the range of alkaline $\mathrm{pH}$ that is lethal to E. coli: E. coli MG1655 withstands exposure to alkaline $\mathrm{pH}$ up to 11.1 with only a moderate reduction of cell counts, whereas incubation at $\mathrm{pH} 11.3$ is lethal to virtually all cells (Figure S1). The mechanism behind this phenomenon remains to be investigated.

\section{Conclusions}

In conclusion, we show here that almost all Enterobacteriaceae known to possess the LHR also have a functional Cpx response, suggesting the possibility of the cross-talk of the Cpx pathway and the LHR. The LHR improves alkaline $\mathrm{pH}$ tolerance only in the presence of chlorine, and this LHR-mediated tolerance to chlorine at alkaline $\mathrm{pH}$ depends on the $\mathrm{Cpx}$ response. In contrast to the $\mathrm{Cpx}$ two-component regulatory system, which contributes to bacterial stress resistance under nonlethal conditions, the LHR functions to protect bacteria against lethal challenges. Our data also indicate that the CpxR response regulator negatively regulates LHR transcription under normal growth conditions to reduce the fitness cost.

Supplementary Materials: The following are available online at https: / www.mdpi.com/article/10 $.3390 /$ microorganisms $9040701 /$ s1, Figure S1: Reduction of viable cell counts of E. coli MG1655 and MG1655 lacZ::LHR and derivative mutant strains at different $\mathrm{pH}$ values

Author Contributions: Conceptualization, L.M.M., T.R. and M.G.G.; methodology, T.Z., Z.W. and D.J.S.; investigation, T.Z. and Z.W.; writing—original draft preparation, T.Z. and M.G.G.; writingreview and editing, all authors; supervision, L.M.M., T.R. and M.G.G.; funding acquisition, L.M.M. and M.G.G. All authors have read and agreed to the published version of the manuscript.

Funding: This research was funded by Alberta Agriculture and Forestry and Alberta Innovates Biosolutions (Grant No. 2019F094R).

Institutional Review Board Statement: Not applicable.

Informed Consent Statement: Not applicable.

Data Availability Statement: The data presented in this study are available on request from the corresponding author.

Conflicts of Interest: The authors declare no conflict of interest. The funders had no role in the design of the study; in the collection, analyses, or interpretation of data; in the writing of the manuscript, or in the decision to publish the results.

\section{References}

1. Johnson, J.R.; Russo, T.A. Extraintestinal pathogenic Escherichia coli: “The other bad E coli". J. Lab. Clin. Med. 2002, 139, 155-162. [CrossRef]

2. Croxen, M.A.; Law, R.J.; Scholz, R.; Keeney, K.M.; Wlodarska, M.; Finlay, B.B. Recent Advances in Understanding Enteric Pathogenic Escherichia coli. Clin. Microbiol. Rev. 2013, 26, 822-880. [CrossRef]

3. Yang, S.-C.; Lin, C.-H.; Aljuffali, I.A.; Fang, J.-Y. Current pathogenic Escherichia coli foodborne outbreak cases and therapy development. Arch. Microbiol. 2017, 199, 811-825. [CrossRef] [PubMed]

4. Baker, C.A.; Rubinelli, P.M.; Park, S.H.; Carbonero, F.; Ricke, S.C. Shiga toxin-producing Escherichia coli in food: Incidence, ecology, and detection strategies. Food Control 2016, 59, 407-419. [CrossRef]

5. Sharma, M.; Beuchat, L.R. Sensitivity of Escherichia coli O157:H7 to Commercially Available Alkaline Cleaners and Subsequent Resistance to Heat and Sanitizers. Appl. Environ. Microbiol. 2004, 70, 1795-1803. [CrossRef] [PubMed]

6. Hurst, J.K.; Barrette, W.C.; Michel, B.R.; Rosen, H. Hypochlorous acid and myeloperoxidase-catalyzed oxidation of iron-slfur clusters in bacterial respiratory dehydrogenases. JBIC J. Biol. Inorg. Chem. 1991, 202, 1275-1282. [CrossRef]

7. Dukan, S.; Touati, D. Hypochlorous acid stress in Escherichia coli: Resistance, DNA damage, and comparison with hydrogen peroxide stress. J. Bacteriol. 1996, 178, 6145-6150. [CrossRef] 
8. Venkobachar, C.; Iyengar, L.; Rao, A.P. Mechanism of disinfection: Effect of chlorine on cell membrane functions. Water Res. 1977, 11, 727-729. [CrossRef]

9. Mendonca, A.F.; Amoroso, T.L.; Knabel, S.J. Destruction of gram-negative food-borne pathogens by high pH involves disruption of the cytoplasmic membrane. Appl. Environ. Microbiol. 1994, 60, 4009-4014. [CrossRef]

10. Wang, Z.; Fang, Y.; Zhi, S.; Simpson, D.J.; Gill, A.; McMullen, L.M.; Neumann, N.F.; Gänzle, M.G. The Locus of Heat Resistance Confers Resistance to Chlorine and Other Oxidizing Chemicals in Escherichia coli. Appl. Environ. Microbiol. 2019, 86, e02123-19. [CrossRef]

11. Zhi, S.; Banting, G.; Li, Q.; Edge, T.A.; Topp, E.; Sokurenko, M.; Scott, C.; Braithwaite, S.; Ruecker, N.J.; Yasui, Y.; et al. Evidence of Naturalized Stress-Tolerant Strains of Escherichia coli in Municipal Wastewater Treatment Plants. Appl. Environ. Microbiol. 2016, 82, 5505-5518. [CrossRef] [PubMed]

12. Mercer, R.G.; Zheng, J.; Garcia-Hernandez, R.; Ruan, L.; Gänzle, M.G.; McMullen, L.M. Genetic determinants of heat resistance in Escherichia coli. Front. Microbiol. 2015, 6, 932. [CrossRef] [PubMed]

13. Boll, E.J.; Marti, R.; Hasman, H.; Overballe-Petersen, S.; Stegger, M.; Ng, K.; Knøchel, S.; Krogfelt, K.A.; Hummerjohann, J.; Struve, C. Turn Up the Heat-Food and Clinical Escherichia coli Isolates Feature Two Transferrable Loci of Heat Resistance. Front. Microbiol. 2017, 8, 579. [CrossRef]

14. Mercer, R.; Nguyen, O.; Ou, Q.; McMullen, L.; Gänzle, M.G. Functional Analysis of Genes Comprising the Locus of Heat Resistance in Escherichia coli. Appl. Environ. Microbiol. 2017, 83, 1400-1417. [CrossRef] [PubMed]

15. Lee, C.; Franke, K.B.; Kamal, S.M.; Kim, H.; Lünsdorf, H.; Jäger, J.; Nimtz, M.; Trček, J.; Jänsch, L.; Bukau, B.; et al. Stand-alone ClpG disaggregase confers superior heat tolerance to bacteria. Proc. Natl. Acad. Sci. USA 2018, 115, E273-E282. [CrossRef] [PubMed]

16. Li, H.; Mercer, R.; Behr, J.; Heinzlmeir, S.; McMullen, L.M.; Vogel, R.F.; Gänzle, M.G. Heat and Pressure Resistance in Escherichia coli Relates to Protein Folding and Aggregation. Front. Microbiol. 2020, 11, 111. [CrossRef]

17. Haslbeck, M. Small Heat Shock Proteins in Bacteria, 1st ed.; de Bruijn, F.J., Ed.; John Wiley \& Sons: Hoboken, NJ, USA, 2016; Volume 2, ISBN 9781119004813.

18. Lee, C.; Wigren, E.; Trček, J.; Peters, V.; Kim, J.; Hasni, M.S.; Nimtz, M.; Lindqvist, Y.; Park, C.; Curth, U.; et al. A novel protein quality control mechanism contributes to heat shock resistance of worldwide-distributed Pseudomonas aeruginosa clone C strains. Environ. Microbiol. 2015, 17, 4511-4526. [CrossRef] [PubMed]

19. Saha, P.; Manna, C.; Chakrabarti, J.; Ghosh, M. Reversible thermal unfolding of a yfdX protein with chaperone-like activity. Sci. Rep. 2016, 6, 29541. [CrossRef]

20. Nishino, K.; Yamaguchi, A. Overexpression of the response regulator evgA of the two-component signal transduction system modulates multidrug resistance conferred by multidrug resistance transporters. J. Bacteriol. 2001, 183, 1455-1458. [CrossRef]

21. Padan, E.; Bibi, E.; Ito, M.; Krulwich, T.A. Alkaline $\mathrm{pH}$ homeostasis in bacteria: New insights. Biochim. Biophys. Acta Biomembr. 2005, 1717, 67-88. [CrossRef]

22. Zwietering, M.H.; Jongenburger, I.; Rombouts, F.M.; Riet, K.V. T Modeling of the Bacterial Growth Curve. Appl. Environ. Microbiol. 1990, 56, 1875-1881. [CrossRef]

23. Ferguson, G.P.; McLaggan, D.; Booth, I.R. Potassium channel activation by glutathione-S-conjugates in Escherichia coli: Protection against methylglyoxal is mediated by cytoplasmic acidification. Mol. Microbiol. 1995, 17, 1025-1033. [CrossRef]

24. Jianming, D.; Shiro, L.; Hoi-Shan, K.; Zhe, L.; Lin, E. The deduced amino-acid sequence of the cloned cpxR gene suggests the protein is the cognate regulator for the membrane sensor, CpxA, in a two-component signal transduction system of Escherichia coli. Gene 1993, 136, 227-230. [CrossRef]

25. Weber, R.F.; Silverman, P.M. The Cpx proteins of Escherichia coli K12. J. Mol. Biol. 1988, 203, 467-478. [CrossRef]

26. Raivio, T.L.; Silhavy, T.J. The $\sigma \mathrm{E}$ and Cpx regulatory pathways: Overlapping but distinct envelope stress responses. Curr. Opin. Microbiol. 1999, 2, 159-165. [CrossRef]

27. Raivio, T.L.; Leblanc, S.K.D.; Price, N.L. The Escherichia coli Cpx Envelope Stress Response Regulates Genes of Diverse Function that Impact Antibiotic Resistance and Membrane Integrity. J. Bacteriol. 2013, 195, 2755-2767. [CrossRef]

28. MacRitchie, D.M.; Ward, J.D.; Nevesinjac, A.Z.; Raivio, T.L. Activation of the Cpx Envelope Stress Response Down-Regulates Expression of Several Locus of Enterocyte Effacement-Encoded Genes in Enteropathogenic Escherichia coli. Infect. Immun. 2008, 76, 1465-1475. [CrossRef]

29. Reisch, C.R.; Prather, K.L.J. The no-SCAR (Scarless Cas9 Assisted Recombineering) system for genome editing in Escherichia coli. Sci. Rep. 2015, 5, 15096. [CrossRef]

30. Cherepanov, P.P.; Wackernagel, W. Gene disruption in Escherichia coli: TcR and KmR cassettes with the option of Flp-catalyzed excision of the antibiotic-resistance determinant. Gene 1995, 158, 9-14. [CrossRef]

31. Datsenko, K.A.; Wanner, B.L. One-step inactivation of chromosomal genes in Escherichia coli K-12 using PCR products. Proc. Natl. Acad. Sci. USA 2000, 97, 6640-6645. [CrossRef]

32. Thomason, L.C.; Costantino, N.; Court, D.L. E. coli Genome Manipulation by P1 Transduction. Curr. Protoc. Mol. Biol. 2007. [CrossRef]

33. Baba, T.; Ara, T.; Hasegawa, M.; Takai, Y.; Okumura, Y.; Baba, M.; Datsenko, K.A.; Tomita, M.; Wanner, B.L.; Mori, H. Construction of Escherichia coli K-12 in-frame, single-gene knockout mutants: The Keio collection. Mol. Syst. Biol. 2006, 2. [CrossRef] 
34. Ma, A.; Chui, L. Identification of heat resistant Escherichia coli by qPCR for the locus of heat resistance. J. Microbiol. Methods 2017, 133, 87-89. [CrossRef]

35. Fang, Y.; Mercer, R.G.; McMullen, L.M.; Gänzle, M.G. Induction of Shiga Toxin-Encoding Prophage by Abiotic Environmental Stress in Food. Appl. Environ. Microbiol. 2017, 83, e01378-17. [CrossRef]

36. Stecher, G.; Tamura, K.; Kumar, S. Molecular Evolutionary Genetics Analysis (MEGA) for macOS. Mol. Biol. Evol. 2020, 37, 1237-1239. [CrossRef]

37. Price, N.L.; Raivio, T.L. Characterization of the Cpx Regulon in Escherichia coli Strain MC4100. J. Bacteriol. 2008, 191, 1798-1815. [CrossRef]

38. De Wulf, P.; Kwon, O.; Lin, E.C.C. The CpxRA Signal Transduction System of Escherichia coli: Growth-Related Autoactivation and Control of Unanticipated Target Operons. J. Bacteriol. 1999, 181, 6772-6778. [CrossRef]

39. Nakayama, S.; Watanabe, H. Involvement of cpxA, a sensor of a two-component regulatory system, in the pH-dependent regulation of expression of Shigella sonnei virF gene. J. Bacteriol. 1995, 177, 5062-5069. [CrossRef] [PubMed]

40. Danese, P.N.; Silhavy, T.J. CpxP, a Stress-Combative Member of the Cpx Regulon. J. Bacteriol. 1998, 180, 831-839. [CrossRef]

41. Lee, L.J.; Barrett, J.A.; Poole, R.K. Genome-Wide Transcriptional Response of Chemostat-Cultured Escherichia coli to Zinc. J. Bacteriol. 2005, 187, 1124-1134. [CrossRef]

42. Yamamoto, K.; Ishihama, A. Characterization of Copper-Inducible Promoters Regulated by CpxA/CpxR in Escherichia coli. Biosci. Biotechnol. Biochem. 2006, 70, 1688-1695. [CrossRef] [PubMed]

43. Clarke, E.J.; Voigt, C.A. Characterization of combinatorial patterns generated by multiple two-component sensors in E. coli that respond to many stimuli. Biotechnol. Bioeng. 2011, 108, 666-675. [CrossRef]

44. Ferguson, G.P.; Munro, A.W.; Douglas, R.M.; McLaggan, D.; Booth, I.R. Activation of potassium channels during metabolite detoxification in Escherichia coli. Mol. Microbiol. 1993, 9, 1297-1303. [CrossRef]

45. Masuda, N.; Church, G.M. Escherichia coli Gene Expression Responsive to Levels of the Response Regulator EvgA. J. Bacteriol. 2002, 184, 6225-6234. [CrossRef]

46. Lee, H.S.; Lee, S.; Kim, J.-S.; Lee, H.-R.; Shin, H.-C.; Lee, M.-S.; Jin, K.S.; Kim, C.-H.; Ku, B.; Ryu, C.-M.; et al. Structural and Physiological Exploration of Salmonella Typhi YfdX Uncovers Its Dual Function in Bacterial Antibiotic Stress and Virulence. Front. Microbiol. 2019, 9, 3329. [CrossRef]

47. Liu, C.-J.; Lin, C.-T.; Chiang, J.-D.; Lin, C.-Y.; Tay, Y.-X.; Fan, L.-C.; Peng, K.-N.; Lin, C.-H.; Peng, H.-L. RcsB regulation of the YfdX-mediated acid stress response in Klebsiella pneumoniae CG43S3. PLoS ONE 2019, 14, e0212909. [CrossRef]

48. Armenteros, J.J.A.; Tsirigos, K.D.; Sønderby, C.K.; Petersen, T.N.; Winther, O.; Brunak, S.; Von Heijne, G.; Nielsen, H. SignalP 5.0 improves signal peptide predictions using deep neural networks. Nat. Biotechnol. 2019, 37, 420-423. [CrossRef] [PubMed]

49. Maurer, L.M.; Yohannes, E.; Bondurant, S.S.; Radmacher, M.; Slonczewski, J.L. pH Regulates Genes for Flagellar Motility, Catabolism, and Oxidative Stress in Escherichia coli K-12. J. Bacteriol. 2005, 187, 304-319. [CrossRef] [PubMed]

50. Dilworth, M.J.; Glenn, A.R. Problems of Adverse $p H$ and Bacterial Strategies to Combat It; Wiley: Chichester, UK, 1999.

51. Hicks, D.B.; Liu, J.; Fujisawa, M.; Krulwich, T.A. F1F0-ATP synthases of alkaliphilic bacteria: Lessons from their adaptations. Biochim. Biophys. Acta Bioenerg. 2010, 1797, 1362-1377. [CrossRef]

52. Mayer, C.; Uslar, M.; Suding, T.; Weidelt, T. pH-dependent expression of periplasmic proteins and amino acid catabolism in Escherichia coli. J. Bacteriol. 2010, 184, 4246-4258. [CrossRef]

53. Enomoto, K.; Koyama, N. Effect of Growth pH on the Phospholipid Contents of the Membranes from Alkaliphilic Bacteria. Curr. Microbiol. 1999, 39, 270-273. [CrossRef] [PubMed]

54. Yang, Y.; Kadim, M.I.; Khoo, W.J.; Zheng, Q.; Setyawati, M.I.; Shin, Y.-J.; Lee, S.-C.; Yuk, H.-G. Membrane lipid composition and stress/virulence related gene expression of Salmonella Enteritidis cells adapted to lactic acid and trisodium phosphate and their resistance to lethal heat and acid stress. Int. J. Food Microbiol. 2014, 191, 24-31. [CrossRef]

55. Krulwich, T.A.; Ito, M.; Hicks, D.B.; Gilmour, R.; Guffanti, A.A. pH homeostasis and ATP synthesis: Studies of two processes that necessitate inward proton translocation in extremely alkaliphilic Bacillus species. Extremophiles 1998, 2, 217-222. [CrossRef]

56. Slonczewski, J.L.; Fujisawa, M.; Dopson, M.; Krulwich, T.A. Cytoplasmic pH Measurement and Homeostasis in Bacteria and Archaea; Elsevier: Amsterdam, The Netherlands, 2009; Volume 55, ISBN 9780123747907.

57. Krulwich, T.A.; Sachs, G.; Padan, E. Molecular aspects of bacterial pH sensing and homeostasis. Nat. Rev. Genet. 2011, 9, 330-343. [CrossRef]

58. Krulwich, T.A.; Hicks, D.B.; Ito, M. Cation/proton antiporter complements of bacteria: Why so large and diverse? Mol. Microbiol. 2009, 74, 257-260. [CrossRef]

59. Nakamura, T.; Tokuda, H.; Unemoto, T. $\mathrm{K}+/ \mathrm{H}+$ antiporter functions as a regulator of cytoplasmic $\mathrm{pH}$ in a marine bacterium, Vibrio alginolyticus. Biochim. Biophys. Acta Biomembr. 1984, 776, 330-336. [CrossRef]

60. Padan, E.; Schuldiner, S. Molecular physiology of the Na+/H+ antiporter in Escherichia coli. J. Exp. Biol. 1994, 196, 443-456.

61. Hunte, C.; Screpanti, E.; Venturi, M.; Rimon, A.; Padan, E.; Michel, H. Structure of a Na+/H+ antiporter and insights into mechanism of action and regulation by pH. Nat. Cell Biol. 2005, 435, 1197-1202. [CrossRef]

62. Saito, H.; Kobayashi, H. Bacterial Responses to Alkaline Stress. Sci. Prog. 2003, 86, 271-282. [CrossRef]

63. Dartigalongue, C.; Raina, S. A new heat-shock gene, ppiD, encodes a peptidyl-prolyl isomerase required for folding of outer membrane proteins in Escherichia coli. EMBO J. 1998, 17, 3968-3980. [CrossRef] 
64. López, C.; Checa, S.K.; Soncinia, F.C. CpxR/CpxA controls scsABCD transcription to counteract copper and oxidative stress in Salmonella enterica Serovar Typhimurium. J. Bacteriol. 2018, 200, 1-13. [CrossRef] [PubMed]

65. Ferguson, G.P.; Booth, I.R. Importance of Glutathione for Growth and Survival of Escherichia coli Cells: Detoxification of Methylglyoxal and Maintenance of Intracellular K+. J. Bacteriol. 1998, 180, 4314-4318. [CrossRef]

66. Elmore, M.J.; Lamb, A.J.; Ritchie, G.Y.; Douglas, R.M.; Munro, A.; Gajewska, A.; Booth, I.R. Activation potassium efflux from Escherichia coli by glutathione metabolites. Mol. Microbiol. 1990, 4, 405-412. [CrossRef]

67. Roosild, T.P.; Castronovo, S.; Healy, J.; Miller, S.; Pliotas, C.; Rasmussen, T.; Bartlett, W.; Conway, S.J.; Booth, I.R. Mechanism of ligand-gated potassium efflux in bacterial pathogens. Proc. Natl. Acad. Sci. USA 2010, 107, 19784-19789. [CrossRef]

68. Harwood, D.T.; Kettle, A.J.; Winterbourn, C.C. Production of glutathione sulfonamide and dehydroglutathione from GSH by myeloperoxidase-derived oxidants and detection using a novel LC-MS/MS method. Biochem. J. 2006, 399, 161-168. [CrossRef]

69. Chesney, J.A.; Eaton, J.W.; Mahoney, J.R. Bacterial glutathione: A sacrificial defense against chlorine compounds. J. Bacteriol. 1996, 178, 2131-2135. [CrossRef]

70. Smirnova, G. Effects of menadione and hydrogen peroxide on glutathione status in growing Escherichia coli. Free. Radic. Biol. Med. 2000, 28, 1009-1016. [CrossRef]

71. Bhat, K.G.; Alex, K. Acid resistance in enteric bacteria. Natl. Med. J. India 1998, 11, 151-152.

72. De Biase, D.; Lund, P.A. The Escherichia coli Acid Stress Response and Its Significance for Pathogenesis; Elsevier: Amsterdam, The Netherlands, 2015; Volume 92, ISBN 978-0-12-802249-8.

73. Lund, P.; Tramonti, A.; De Biase, D. Coping with low pH: Molecular strategies in neutralophilic bacteria. FEMS Microbiol. Rev. 2014, 38, 1091-1125. [CrossRef]

74. Richard, H.; Foster, J.W. Escherichia coli Glutamate and Arginine-Dependent Acid Resistance Systems Increase Internal pH and Reverse Transmembrane Potential. J. Bacteriol. 2004, 186, 6032-6041. [CrossRef]

75. Castanie-Cornet, M.-P.; Penfound, T.A.; Smith, D.; Elliott, J.F.; Foster, J.W. Control of Acid Resistance in Escherichia coli. J. Bacteriol. 1999, 181, 3525-3535. [CrossRef]

76. Iyer, R.; Williams, C.; Miller, C. Arginine-Agmatine Antiporter in Extreme Acid Resistance in Escherichia coli. J. Bacteriol. 2003, 185, 6556-6561. [CrossRef]

77. Meng, S.Y.; Bennett, G.N. Nucleotide sequence of the Escherichia coli cad operon: A system for neutralization of low extracellular pH. J. Bacteriol. 1992, 174, 2659-2669. [CrossRef]

78. Kern, R.; Malki, A.; Abdallah, J.; Tagourti, J.; Richarme, G. Escherichia coli HdeB Is an Acid Stress Chaperone. J. Bacteriol. 2006, 189, 603-610. [CrossRef] 